\title{
Macrolide-lincosamide-streptogramin resistance phenotypes and genotypes of coagulase-positive Staphylococcus aureus and coagulase-negative staphylococcal isolates from bovine mastitis
}

\author{
Longping $\mathrm{Li}^{1}$, Weiwei Feng ${ }^{1}$, Zhiping Zhang ${ }^{1}$, Huping Xue ${ }^{1}$ and Xin Zhao ${ }^{1,2^{*}}$
}

\begin{abstract}
Background: There are limited data available on macrolide-lincosamide-streptogramin (MLS) resistance of Staphylococcus aureus (S. aureus) and coagulase-negative staphylococci (CoNS) from bovine milk in China. To address this knowledge gap, MLS resistance was determined in $121 \mathrm{~S}$. aureus and 97 CoNS isolates. Minimum inhibitory concentrations (MICs) of MLS antibiotics were determined by an agar dilution method, while differentiation of MLS phenotypes was performed by a double-disc diffusion test. MLS resistance genotypes were determined by PCR for corresponding resistance genes.

Results: Forty (33.1\%) S. aureus and 65 (67.0\%) CoNS were resistant to erythromycin, whereas all 218 isolates were susceptible to quinupristin/dalfopristin. Among 40 erythromycin-resistant (ER-R) S. aureus and 65 ER-R CoNS isolates, $38 \mathrm{~S}$. aureus and 40 CoNS isolates exhibited the inducible MLS (iMLS) resistance phenotype and 2 S. aureus and 20 CoNS isolates expressed the constitutive MLS resistance (CMLS) phenotype. At the same time, 5 CoNS isolates exhibited resistance to erythromycin but susceptibility to clindamycin (the MS phenotype). An inactivating enzyme gene $\ln u(A)$, methylase genes $\operatorname{erm}(C)$ and $\operatorname{erm}(B)$, efflux genes $m s r(A) / m s r(B)$, a phosphotransferase gene $m p h(C)$, an esterase gene ere(A) and the streptogramin resistance determinant $v g a(A)$ were detected individually or in combinations. Among them, genes $\operatorname{In} u(A)$, erm $(C)$ and $m p h(C)$ predominated. The ereA gene was detected for the first time in staphylococci of bovine milk origin. Resistance genes also existed in erythromycin-susceptible isolates.

Conclusions: Our study demonstrated a high level of resistance to MLS antibiotics in staphylococci from bovine mastitic milk, especially with a high rate of the iMLS phenotype in S. aureus isolates. These data suggest that MLS antibiotics should be used judiciously to treat or prevent bovine mastitis caused by staphylococci.
\end{abstract}

Keywords: Macrolide resistance, Disk-diffusion induction test, Staphylococci, Bovine milk

\section{Background}

Bovine mastitis is the most costly disease for the dairy industry worldwide. Although a wide variety of pathogens have been isolated as causative agents of this disease, Staphylococcus aureus (S. aureus) is considered as one of the most important pathogens due to its resistance to certain antibiotics and its propensity to recur chronically. Recently, coagulase-negative staphylococci (CoNS) have been

\footnotetext{
* Correspondence: zhaoxin@nwsuaf.edu.cn

${ }^{1}$ College of Animal Science and Technology, Northwest A\&F University, Yang Ling, Shaanxi, P. R. China

${ }^{2}$ Department of Animal Science, McGill University, 21,111 Lakeshore, Ste. Anne de Bellevue H9X 3 V9, QC, Canada
}

considered as opportunistic pathogens that cause bovine mastitis in many countries and could be therefore described as emerging mastitis pathogens $[1,2]$. Increasing attention has been paid to CoNS in both subclinical and clinical mastitis cases throughout the world [3, 4]. Macrolidelincosamide-streptogramin (MLS) antibiotics, including erythromycin, clindamycin and spiramycin, are frequently used for treatment of bovine mastitis $[5,6]$. Thus, results from an in vitro susceptibility testing are an important tool to guide a veterinarian in selecting the most efficacious antimicrobial agent(s) for therapeutic and prophylactic intervention. 
Three mechanisms are mainly responsible for acquiring resistance to MLS antibiotics in staphylococci: (1) target site modifications by methylation or mutation; (2) active efflux of antibiotics; or (3) inactivation of antibiotics. The first mechanism includes target site modifications by a methylase encoded by one or more of the erm genes, methylating 23S rRNA and thereby altering binding sites for MLS antibiotics [7]. Phenotypically, this resistance appears either inducible (resistant to 14- and 15-membered macrolides and susceptible to 16-membered macrolides, lincosamides and streptogramin B) or constitutive (resistant to all forms of these antibiotics) [8]. The second mechanism involves a macrolide efflux pump encoded by $\operatorname{msr}(A)$ and/or $m s r(B)$ genes. This pump protein belongs to the $\mathrm{ABC}$ transporter family and exports 14-membered macrolides and streptogramin B antibiotics from bacterial cells, while lincosamide and streptogramin A antibiotics remain unaffected (the MS phenotype) [9]. The third mechanism encompasses several enzymes. A lincosamide nucleotidyltransferase encoded by the $\ln u(A)$ gene confers resistance only to lincosamides and has been detected in CoNS isolates from bovine mastitis [10]. Esterases encoded by $\operatorname{ere}(A) /(B)$ genes hydrolyze the lactone ring of the macrocyclic nucleus [11]. Furthermore, $\operatorname{vga}(A) /(B)$ genes have been characterized as a determinant of streptogramin A resistance [11]. Finally, the macrolide phosphotransferase $C$ encoded by the $m p h(C)$ gene inactivates some macrolide antibiotics and has been detected in CoNS isolated from bovine subclinical mastitis [12].

The reported resistance of S. aureus and CoNS isolated from bovine mastitis to MLS antibiotics in different countries was generally low $[12,13]$. Meanwhile, there was a paucity of data regarding MLS-resistance phenotypes and genotypes of $S$. aureus and CoNS isolated from bovine mastitis in China, except one study [5]. The objective of this study was to determine the MLS resistance phenotypes and genotypes of $121 \mathrm{~S}$. aureus and 97 CoNS isolates from mastitic milk from dairy farms of the Shaanxi province in Northwestern China.

\section{Methods}

\section{Bacterial isolates}

Milk samples were obtained from dairy cows with clinical mastitis under the ethical approval granted by the College of Animal Science and Technology, the Northwest Agriculture and Forestry (A\&F) University (Permit Number: NWAFU1008), as described previously [14]. A total of 121 coagulase-positive S. aureus (CoPSA) and 97 coagulase-negative staphylococci (CoNS) were used in this study. CoNS species were identified by sequencing analyses based on $\operatorname{sodA}$ and/or gap genes [14]. Ninety-seven CoNS isolates encompassed 9 CoNS species: Staphylococcus haemolyticus (S. haemolyticus, $\mathrm{n}=31$ ), Staphylococcus aureus (S. aureus, $\mathrm{n}=28$ ), Staphylococcus chromogenes (S. chromogenes, $\mathrm{n}=11)$, Staphylococcus sciuri (S. sciuri, $\mathrm{n}=9$ ),
Staphylococcus epidermidis (S. epidermidis, $\mathrm{n}=7$ ), Staphylococcus simulans (S. simulans, $\mathrm{n}=5)$, Staphylococcus hyicus (S. hyicus, $\mathrm{n}=3$ ), Staphylococcus warneri (S. warneri, $\mathrm{n}=2$ ) and Staphylococcus saprophyticus (S. saprophyticus, $\mathrm{n}=1$ ).

\section{Antibiotic susceptibility testing}

Minimum inhibitory concentrations (MICs) of antimicrobial agents, including 14-membered (erythromycin), 15membered (azithromycin), 13- and 15-membered mixture (tulathromycin) and 16-membered (tylosin and spiramycin) macrolides, lincosamides (clindamycin) and streptogramins (quinupristin/dalfopristin) were determined using an agar dilution method. Clindamycin, azithromycin, tulathromycin and spiramycin were purchased from Dalian Meilun Biology Technology Co., Ltd. (Dalian, China). Tylosin was purchased from Shanghai Kai Yang Biotechnology Co., Ltd. (Shanghai, China). Erythromycin was bought from SigmaAldrich (Beijing, China) and quinupristin/dalfopristin was obtained from Santa Cruz biotechnology, Inc. (Shanghai, China). The approved veterinary specific CLSI MIC breakpoints of erythromycin and clindamycin are $\geq 8 \mu \mathrm{g} / \mathrm{mL}$ and $4 \mu \mathrm{g} / \mathrm{mL}$, respectively [15]. MIC breakpoint for spiramycin $(\geq 32 \mu \mathrm{g} / \mathrm{mL})$ was adopted from the Swedish Antibiotic Utilisation and Resistance in Human Medicine (SWEDRES) and Swedish Veterinary Antimicrobial Resistance Monitoring (SVARM) system (SWEDRESSVARM) [16]. The MIC breakpoint for tylosin $(\geq 20 \mu \mathrm{g} / \mathrm{mL})$ was based on the Veterinary Antimicrobial Decision Support (VADS) according to a previous study [5]. There were no veterinary specific CLSI, VADS or SWEDRESSVARM-approved breakpoints for azithromycin and quinupristin-dalfopristin. Therefore, we used a human specific CLSI document M100-S21 [17] as a reference to determine breakpoints for azithromycin $(\geq 8 \mu \mathrm{g} / \mathrm{mL})$ and quinupristin-dalfopristin $(\geq 4 \mu \mathrm{g} / \mathrm{mL})$. In addition, there was no CLSI, VADS or SVARM-approved breakpoint for tulathromycin. The standard reference strain $S$. aureus ATCC 29213 served as a quality control in every test run.

\section{Detection of MLS resistance phenotypes}

In order to differentiate different types of resistance phenotype for erythromycin-resistant (ER-R) isolates, a doubledisk diffusion test ( $\mathrm{D}$ test) was performed with erythromycin $(15 \mu \mathrm{g} /$ disc $)$ and clindamycin $(2 \mu \mathrm{g} /$ disc $)$, following the procedure recommended by CLSI [17]. Staphylococcal isolates showing resistance to erythromycin (zone size $\leq 13 \mathrm{~mm}$ ) but being sensitive to clindamycin (zone size $\geq 21 \mathrm{~mm}$ ) and producing a D-shaped zone of inhibition around clindamycin with flattening towards erythromycin disc was defined as having an inducible type of MLS resistance ( $\mathrm{D}^{+}$, iMLS). In addition, resistance to erythromycin (zone size $\leq 13 \mathrm{~mm}$ ) as well as to clindamycin (zone size $\leq 14 \mathrm{~mm}$ ) indicated a constitutive type of 
MLS resistance (cMLS). Staphylococcal isolates showing resistance to erythromycin (zone size $\leq 13 \mathrm{~mm}$ ) while being sensitive to clindamycin (zone size $\geq 21 \mathrm{~mm}$ ) with no blunting zone were classified as the MS phenotype.

\section{Detection of MLS resistance genotypes}

Staphylococcal isolates were incubated in the Brain Heart Infusion broth (Oxoid) at $37^{\circ} \mathrm{C}$ for $16-18 \mathrm{~h}$. Then, bacteria were harvested by centrifugation. Plasmid and chromosome DNA of bacterial isolates were extracted using a commercial DNAout kit (Tiandz Inc., Beijing, China) as described previously [14]. The screening of MLS resistance determinants including methylase genes $\operatorname{erm}(A), \operatorname{erm}(B)$ and $\operatorname{erm}(C)$; phosphotransferase genes $m p h(A)$ and $m p h(C)$; lincosamide nucleotidyltransferase genes $\ln u(A)$ and $\ln u(B)$; erythromycin esterase genes $\operatorname{ere}(A)$ and $\operatorname{ere}(B)$; streptogramin resistance genes $v g a(A), v g a(B), v g b(A)$ and $v g b(B)$, and the macrolide efflux determinants $m s r(A) / m s r(B)$ was performed by PCR using the specific primers as described in previous studies [11, 12, 18-20]. PCR products were randomly selected and sequenced to ensure specificity and accuracy. Sequence comparisons were performed using the Basic Local Alignment Search Tool (BLAST) program (http://www.ncbi.nlm.nih.gov/BLAST/).

\section{Results and discussion}

\section{Characterization of MLS resistance phenotypes in} erythromycin-resistant isolates and MIC distribution Of the 121 coagulase-positive S. aureus (CoPSA) isolates, 40 were resistant to at least one MLS antibiotic. Thirtyeight out of 40 ER-R CoPSA (95\%) isolates exhibited iMLS phenotypes, whereas only 2 isolates expressed cMLS phenotypes, with no MS phenotype. The MICs of the macrolides and lincosamides antibiotics for the 40 ER-R CoPSA isolates are summarized in Table 1. Among ER-R CoPSA, $100 \%, 100 \%, 80 \%, 17.5 \%$ and $5 \%$ of isolates were resistant to erythromycin, azithromycin, spiramycin, tylosin and clindamycin, respectively. The $\mathrm{MIC}_{50}$ and $\mathrm{MIC}_{90}$ values of 14-membered, 15-membered macrolides and 16 -membered macrolide spiramycin were $\geq 128 \mu \mathrm{g} / \mathrm{mL}$, while the $\mathrm{MIC}_{50}$ values of 16 -membered macrolides tylosin and lincosamides were in the susceptible range. No isolate expressed resistance to quinupristin/dalfopristin (MICs $\leq 1 \mu \mathrm{g} / \mathrm{mL}$ ).

Among 97 CoNS isolates, 65 isolates exhibited MLS resistance phenotypes. Among them, 40 showed the iMLS phenotype and 20 expressed the cMLS phenotype, while 5 exhibited the MS phenotype. The MICs of the antimicrobial agents tested are summarized in Table 2. Eighteen isolates with cMLS phenotypes exhibited a high-level of resistance to erythromycin, clindamycin, azithromycin, spiramycin and tylosin with MIC values of $\geq 256 \mu \mathrm{g} / \mathrm{mL}$. Furthermore, $1 \mathrm{~S}$. haemolyticus with the iMLS phenotype exhibited MICs $\geq 256 \mu \mathrm{g} / \mathrm{mL}$ for erythromycin and azithromycin while MICs for spiramycin and tylosin were $64 \mu \mathrm{g} / \mathrm{mL}$ and $128 \mu \mathrm{g} / \mathrm{mL}$, respectively. In addition, 39 CoNS isolates with the iMLS phenotype showed a complete cross-resistance to erythromycin and azithromycin with MICs of $\geq 256 \mu \mathrm{g} / \mathrm{mL}$. However, MIC values of 16-membered macrolides tylosin $(2-8 \mu \mathrm{g} / \mathrm{mL})$ and spiramycin $(2-16 \mu \mathrm{g} / \mathrm{mL})$ were in the susceptible ranges.

The iMLS phenotype rate of ER-R S. aureus (38/40) and ER-R CoNS (40/65) isolates was much higher in this study than previous studies, underlining the importance of routine screening of bovine $S$. aureus and CoNS isolates for inducible resistance phenotypes. Wang et al. [5] reported that the inducible MLS resistance phenotype was detected in 38 out of $72 \mathrm{~S}$. aureus isolates from cows with clinical mastitis in Inner Mongolia of China. In another study, only 3 isolates with the iMLS phenotype were found out of 22 ER-R CoNS in Germany [12]. The reason for the higher rate of the iMLS phenotype in our study is not clear.

Table 1 Minimum inhibitory concentrations (MICs) of 40 ER-R coagulase-positive S. aureus isolates

\begin{tabular}{|c|c|c|c|c|c|c|c|c|c|c|c|c|c|c|}
\hline \multirow[t]{2}{*}{ Antibiotic agents } & \multicolumn{12}{|c|}{ The number of isolates inhibited in different MICs $\left(\mu \mathrm{g} \mathrm{mg}^{-1}\right)^{a}$} & \multirow[t]{2}{*}{ MIC50 } & \multirow[t]{2}{*}{ MIC90 } \\
\hline & $\leq 0.125$ & 0.25 & 0.5 & 1 & 2 & 4 & 8 & 16 & 32 & 64 & 128 & $\geq 256$ & & \\
\hline Erythromycin $^{\mathrm{b}}$ & 0 & 0 & 0 & 0 & 0 & 0 & 0 & 1 & 3 & 2 & 6 & 28 & $>256$ & $>256$ \\
\hline Clindamycin ${ }^{\mathrm{b}}$ & 24 & 7 & 0 & 1 & 6 & 0 & 0 & 0 & 0 & 0 & 0 & 2 & 0.125 & 2 \\
\hline Spiramycin $^{c}$ & 0 & 0 & 0 & 0 & 0 & 0 & 3 & 5 & 0 & 2 & 30 & 0 & $>128$ & $>128$ \\
\hline Tylosin $^{d}$ & 0 & 0 & 3 & 5 & 25 & 0 & 0 & 0 & 2 & 2 & 2 & 1 & 2 & 64 \\
\hline Azithromycin ${ }^{b}$ & 0 & 0 & 0 & 0 & 0 & 0 & 0 & 0 & 0 & 4 & 0 & 36 & $>256$ & $>256$ \\
\hline Quinupristin-dalfopristin ${ }^{b}$ & 23 & 11 & 6 & 0 & 0 & 0 & 0 & 0 & 0 & 0 & 0 & 0 & 0.125 & 0.25 \\
\hline Tulathromycin ${ }^{e}$ & 0 & 0 & 0 & 0 & 0 & 0 & 0 & 0 & 0 & 0 & 5 & 35 & $>256$ & $>256$ \\
\hline
\end{tabular}

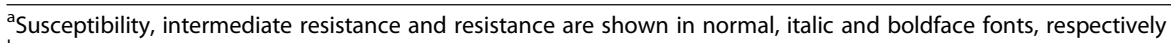

${ }^{\mathrm{b}} \mathrm{MIC}$ breakpoints for erythromycin, azithromycin, clindamycin and quinupristin-dalfopristin were based on Clinical and Laboratory Standards Institute (CLSI) documents (CLSI, 2004, 2011)

${ }^{c}$ MIC breakpoints of spiramycin were based on the SWEDRES-SVARM (2012)

${ }^{\mathrm{d}}$ MIC breakpoints of tylosin were based on the VADS according to a previous study [5]

${ }^{\mathrm{e}} \mathrm{MIC}$ breakpoints of this antibiotic were not available

$\mathrm{MIC}_{50}$, the MIC for $50 \%$ of the organisms

$\mathrm{MIC}_{90}$, the MIC for $90 \%$ of the organisms 
Table 2 Minimum inhibitory concentrations (MICs) of 97 CoNS isolates

\begin{tabular}{|c|c|c|c|c|c|c|c|c|c|c|c|c|c|}
\hline \multirow[t]{2}{*}{ Test agent } & \multirow[t]{2}{*}{ Species } & \multicolumn{12}{|c|}{ The number of isolates inhibited in different MICs $\left(\mu \mathrm{g} \mathrm{mg}{ }^{-1}\right)^{a}$} \\
\hline & & 0.125 & 0.25 & 0.5 & 1 & 2 & 4 & 8 & 16 & 32 & 64 & 128 & $\geq 256$ \\
\hline \multirow[t]{9}{*}{ Erythromycin ${ }^{\mathrm{b}}$} & S. chromogenes & & 2 & 3 & & & & 1 & & & & & 5 \\
\hline & S. sciuri & & 2 & 5 & & & & & & & 1 & & 1 \\
\hline & S. warneri & & & & & & & & & 1 & 1 & & \\
\hline & S. haemolyticus & & & 1 & & & & & & & & & 30 \\
\hline & S. epidermidis & & & & & 1 & & & & & & & 6 \\
\hline & S. hyicus & & & & & & & & & & & & 3 \\
\hline & S. saprophyticus & & & & & & & & & & & 1 & \\
\hline & S. simulans & & & & & 1 & & & & & & & 4 \\
\hline & S. aureus & & 12 & 5 & & & & 1 & & & & & 10 \\
\hline \multirow[t]{9}{*}{ Clindamycin ${ }^{b}$} & S. chromogenes & 6 & 1 & & & 3 & & & & & & & 1 \\
\hline & S. sciuri & 1 & & & & 7 & & & & & & & 1 \\
\hline & S. warneri & 2 & & & & & & & & & & & \\
\hline & S. haemolyticus & 1 & 8 & & & 10 & & & & & & & 12 \\
\hline & S. epidermidis & 1 & 1 & & & 4 & & & & & & & 1 \\
\hline & S. hyicus & & & & & & & & & & & & 3 \\
\hline & S. saprophyticus & & & & & 1 & & & & & & & \\
\hline & S. simulans & & & & & 3 & & & & & & & 2 \\
\hline & S. aureus & 16 & 6 & & & 6 & & & & & & & \\
\hline \multirow[t]{9}{*}{ Spiramycin $^{c}$} & S. chromogenes & & & & & 2 & 3 & 3 & 2 & & & & 1 \\
\hline & S. sciuri & & & & & 1 & 5 & 2 & & & & & 1 \\
\hline & S. warneri & & & & & & & 2 & & & & & \\
\hline & S. haemolyticus & & & & & 3 & 1 & 13 & 1 & & & & 13 \\
\hline & S. epidermidis & & & & & 1 & 1 & 2 & 2 & & & & 1 \\
\hline & S. hyicus & & & & & & & & & & & & 3 \\
\hline & S. saprophyticus & & & & & & & 1 & & & & & \\
\hline & S. simulans & & & & & & & & & & & 3 & 2 \\
\hline & S. aureus & & & & & 3 & 5 & 17 & 3 & & & & \\
\hline \multirow[t]{9}{*}{ Tylosin ${ }^{d}$} & S. chromogenes & & & & 1 & 7 & & 2 & & & & & 1 \\
\hline & S. sciuri & & & & & 6 & & 2 & & & 1 & & \\
\hline & S. warneri & & & & & 1 & & 1 & & & & & \\
\hline & S. haemolyticus & & & & & 13 & & 4 & & 1 & & 1 & 12 \\
\hline & S. epidermidis & & 1 & & & 1 & & 4 & & & & & 1 \\
\hline & S. hyicus & & & & & & & & & & & & 3 \\
\hline & S. saprophyticus & & & & & & & 1 & & & & & \\
\hline & S. simulans & & & & & 2 & & & 1 & & & & 2 \\
\hline & S. aureus & & & & 2 & 20 & & 5 & & & & & 1 \\
\hline \multirow[t]{6}{*}{ azithromycin $^{\mathrm{b}}$} & S. chromogenes & 1 & 1 & & & & & & & 3 & & 1 & 5 \\
\hline & S. sciuri & 2 & & & & & & & & 5 & 1 & & 1 \\
\hline & S. warneri & & & & & & & & & & 2 & & \\
\hline & S. haemolyticus & & & & & & 1 & & & & & & 30 \\
\hline & S. epidermidis & & & & & & 1 & & & & & & 6 \\
\hline & S. hyicus & & & & & & & & & & & & 3 \\
\hline
\end{tabular}


Table 2 Minimum inhibitory concentrations (MICs) of 97 CoNS isolates (Continued)

\begin{tabular}{|c|c|c|c|c|c|c|c|c|c|c|c|c|c|}
\hline & S. saprophyticus & & & & & & & & & & & 1 & \\
\hline & S. simulans & & & & & & & 1 & & & & & 4 \\
\hline & S. aureus & 6 & 4 & & & & & 2 & & 6 & & & 10 \\
\hline \multirow[t]{9}{*}{ quinupristin-dalfopristin ${ }^{b}$} & S. chromogenes & & 1 & 5 & 4 & 1 & & & & & & & \\
\hline & S. sciuri & & & 1 & & 8 & & & & & & & \\
\hline & S. warneri & & & 1 & 1 & & & & & & & & \\
\hline & S. haemolyticus & & & 5 & 23 & 3 & & & & & & & \\
\hline & S. epidermidis & & & 6 & & 1 & & & & & & & \\
\hline & S. hyicus & & & 2 & 1 & & & & & & & & \\
\hline & S. saprophyticus & & & 1 & & & & & & & & & \\
\hline & S. simulans & & & & 5 & & & & & & & & \\
\hline & S. aureus & 1 & 1 & 7 & 18 & 1 & & & & & & & \\
\hline \multirow[t]{9}{*}{ Tulathromycin ${ }^{e}$} & S. chromogenes & & & & & & 3 & & 3 & & 1 & 1 & 3 \\
\hline & S. sciuri & & & & & & 2 & & 6 & & & & 1 \\
\hline & S. warneri & & & & & & 1 & & 1 & & & & \\
\hline & S. haemolyticus & & & & & & & & 1 & & 8 & 2 & 20 \\
\hline & S. epidermidis & & & & & & 1 & & & & 1 & & 5 \\
\hline & S. hyicus & & & & & & & & & & & & 3 \\
\hline & S. saprophyticus & & & & & & 1 & & & & & & \\
\hline & S. simulans & & & & & & 1 & & & & 2 & & 2 \\
\hline & S. aureus & & & & & & 12 & & 5 & 1 & 3 & 3 & 4 \\
\hline
\end{tabular}

\section{Characterization of MLS resistance genotypes in erythromycin-resistant isolates}

Among 40 ER-R CoPSA isolates, the most dominant resistance gene was $\operatorname{erm}(C)(38 / 40)$, followed by the $\operatorname{mph}(C)$ (27/40), $\operatorname{erm}(B)(14 / 40), \operatorname{ere}(A)(14 / 40)$ and $v g a(A)(10 / 40)$ (Table 3$)$. The $m s r(A) / m s r(B)$ genes were found in 6 isolates, which were all positive for $\operatorname{erm}(C)$ or $\operatorname{erm}(B)$ genes and displayed iMLS phenotypes (Table 4). Considering the 65 ER-R CoNS isolates, $m s r(A) / m s r(B)$ genes were present in 51 isolates, $\operatorname{erm}(C)$ in 46, $\operatorname{erm}(B)$ in 23, $m p h(C)$ in 25, $v g a(A)$ in 23 and $\operatorname{ere}(A)$ in 9 isolates. At least one of the MLS resistance genes was detected in each ER-R isolate. The simultaneous presence of two or more MLS antibiotic resistance genes was also detected (Table 4). The simultaneous presence of two or more macrolide resistance genes in the same $S$. aureus or CoNS isolate is well-known and has been reported previously for S. aureus or CoNS isolates from bovine mastitis $[5,12,21]$.

\section{Correlation between the MIC values of MLS resistance phenotypes and phenotypes}

The possible relationship between MLS resistance phenotypes and genotypes was also explored. Among the 40
ER-R CoPSA isolates, 8 isolates with iMLS phenotypes were sensitive to 16-membered macrolides spiramycin and 32 isolates with iMLS phenotypes were sensitive to tylosin. Those isolates were all $\operatorname{erm}(B)$ and/or $\operatorname{erm}(C)$ positive. As for the 65 ER-R CoNS isolates, $4 \operatorname{erm}(B)$ and/or $\operatorname{erm}(C)$ positive isolates with the MS phenotype and $28 \operatorname{erm}(B)$ and/or $\operatorname{erm}(C)$ positive isolates with the iMLS phenotype were sensitive to 16-membered macrolides spiramycin and tylosin, respectively. Furthermore, $1 S$. warneri with the MS phenotype and 9 CoNS isolates with the iMLS phenotype were also sensitive to 16-membered macrolides spiramycin and tylosin. Those 10 isolates were negative for erm genes but positive for other MLS resistance genes, such as $m s r(A) /(B), \operatorname{mph}(C), \operatorname{ere}(A), \ln u(A)$ or $\operatorname{vga}(A)$. In general, erm-carrying ER-R $S$. aureus and CoNS isolates with iMLS or MS phenotypes possessed a high degree of resistance to erythromycin, azithromycin and clindamycin (inducible), while having a low rate of resistance to 16-membered macrolides tylosin and/or spiramycin.

It has been reported that the lactone rings of 16- and 14-membered macrolides adopt distinctly diverse conformations, thereby enabling the former compounds to avoid steric hindrance with the nucleotide A2058 mutation in 
Table 3 MLS resistance phenotypes and genotypes in ER-R coagulase-positive S. aureus and ER-R CoNS isolates

\begin{tabular}{|c|c|c|c|c|c|c|c|c|c|c|c|c|c|c|c|}
\hline \multirow[t]{2}{*}{ Species } & \multirow{2}{*}{$\begin{array}{l}\text { Total } \\
\text { number }\end{array}$} & \multirow{2}{*}{$\begin{array}{l}\text { Erythromycin- } \\
\text { resistant } \\
\text { number }\end{array}$} & \multicolumn{6}{|c|}{ Phenotype } & \multicolumn{7}{|c|}{ The number of isolates containing resistance genes } \\
\hline & & & iMLS & $\%$ & cMLS & $\%$ & MS & $\%$ & $\ln u A$ & ermB & ermC & $m s r A / B$ & $m p h C$ & ereA & $\operatorname{vgaA}$ \\
\hline S. chromogenes & 11 & 6 & 5 & 83.3 & 1 & 16.7 & 0 & 0 & 6 & 2 & 3 & 3 & 1 & 1 & 2 \\
\hline S. sciuri & 9 & 2 & 0 & 50 & 1 & 0 & 1 & 50 & 2 & 2 & 0 & 1 & 0 & 0 & 0 \\
\hline S. warneri & 2 & 2 & 0 & 0 & 0 & 0 & 2 & 100 & 2 & 1 & 0 & 1 & 1 & 0 & 0 \\
\hline S. haemolyticus & 31 & 30 & 18 & 62 & 12 & 40 & 0 & 0 & 30 & 11 & 22 & 26 & 14 & 4 & 12 \\
\hline S. epidermidis & 7 & 6 & 5 & 83.3 & 1 & 16.7 & 0 & 0 & 6 & 2 & 6 & 7 & 1 & 1 & 1 \\
\hline S. hyicus & 3 & 3 & 0 & 0 & 3 & 100 & 0 & 0 & 3 & 3 & 2 & 2 & 1 & 1 & 1 \\
\hline S. saprophyticus & 1 & 1 & 0 & 0 & 0 & 0 & 1 & 100 & 1 & 0 & 1 & 1 & 1 & 0 & 1 \\
\hline S. simulans & 5 & 4 & 2 & 50 & 2 & 50 & 0 & 0 & 4 & 0 & 2 & 2 & 1 & 0 & 4 \\
\hline CoN S. aureus ${ }^{a}$ & 28 & 11 & 10 & 91 & 0 & 0 & 1 & 9 & 11 & 3 & 10 & 8 & 5 & 2 & 2 \\
\hline Total CoNS & 97 & 65 & 40 & 61.5 & 20 & 30.8 & 5 & 7.7 & 65 & 23 & 46 & 51 & 25 & 9 & 23 \\
\hline CoP S. aureus b & 121 & 40 & 38 & 95 & 2 & 5 & 0 & 0 & 40 & 14 & 38 & 6 & 27 & 14 & 10 \\
\hline
\end{tabular}

iMLS, inducible expression of clindamycin resistance

CMLS, constitutive expression of clindamycin resistance

MS, erythromycin-resistant, clindamycin-susceptible, no induction

CoN S. aureus ${ }^{a}$, coagulase-negative S. aureus

CoP S. aureus ${ }^{b}$, coagulase-positive $S$. aureus

E. coli [22]. Such a mechanism may be also responsible for differential sensitivity to 16- and 14-membered macrolides in staphylococci. In addition, differential effects of 14 and 15-membered macrolides versus 16 -membered macrolides on expression of erm genes could contribute to our results. Expression of erm genes can be either inducible or constitutive. Inducible erm genes expression is controlled at a post-transcriptional level, which involves a structure upstream from the erm gene composing of a leader peptide and a series of inverted repeats. Formation of different mRNA secondary structures in this regulatory region in the presence or absence of an inducer allows or prevents the translation of the erm gene transcripts [8]. Only 14and 15-membered macrolide can induce erm expression, while 16-membered macrolides, lincosamides, or streptogramins are not able to induce erm gene expression [8]. However, why 10 CoNS without the erm gene were also sensitive to 16-membered macrolides spiramycin and tylosin in this study is unclear and will be further studied. In addition, previous studies have shown that erm gene expression can quickly and irreversibly switch from inducible expression to constitutive expression under selective pressure due to the structural alterations (sequence deletions of varying length, duplications and mutations),

Table 4 Combinations of MLS resistance genes in 40 ER-R COPSA and 65 ER-R CoNS isolates

\begin{tabular}{|c|c|c|c|c|c|c|c|c|c|c|c|c|c|c|c|c|c|c|}
\hline \multirow[t]{2}{*}{ Species } & \multirow{2}{*}{$\begin{array}{l}\text { Total } \\
\text { number }\end{array}$} & \multirow{2}{*}{$\begin{array}{l}\text { Erythromycin- } \\
\text { resistant } \\
\text { number }\end{array}$} & \multicolumn{4}{|c|}{ ermB+ermC } & \multicolumn{4}{|c|}{ erm $C+m s r A / m s r B$} & \multicolumn{4}{|c|}{$e r m C+m p h C$} & \multicolumn{4}{|c|}{$e r m C+m s r A / m s r B+m p h C$} \\
\hline & & & $\mathrm{n}$ & iMLS & CMLS & $\overline{M S}$ & $n$ & iMLS & CMSL & $\overline{M S}$ & $\mathrm{n}$ & iMLS & CMLS & $\overline{M S}$ & $\mathrm{n}$ & iMLS & CMLS & MS \\
\hline S. chromogenes & 11 & 6 & 1 & 1 & & & 1 & 1 & & & 1 & 1 & & & & & & \\
\hline S. sciuri & 9 & 2 & & & & & & & & & & & & & & & & \\
\hline S. warneri & 2 & 2 & & & & & & & & & & & & & & & & \\
\hline S. haemolyticus & 31 & 30 & 11 & 5 & 6 & & 19 & 12 & 7 & & 12 & 8 & 4 & & 11 & 5 & 6 & \\
\hline S. epidermidis & 7 & 6 & 1 & & 1 & & 4 & 3 & 1 & & 1 & 1 & & & 1 & 1 & & \\
\hline S. hyicus & 3 & 3 & 2 & & 2 & & 2 & & 2 & & & & & & 1 & 1 & & \\
\hline S. saprophyticus & 1 & 1 & & & & & 1 & & & 1 & 1 & & & 1 & 1 & & & 1 \\
\hline S. simulans & 5 & 4 & & & & & 1 & & 1 & & 1 & & 1 & & 1 & & 1 & \\
\hline CoN S. aureus ${ }^{a}$ & 28 & 11 & 2 & 2 & & & 8 & 7 & & 1 & 5 & 4 & & 1 & 3 & 2 & & 1 \\
\hline Total CoNS & 97 & 65 & 17 & 8 & 9 & 0 & 36 & 23 & 11 & 2 & 21 & 14 & 5 & 2 & 18 & 9 & 7 & 2 \\
\hline CoP S. aureus ${ }^{b}$ & 121 & 40 & 18 & 17 & 1 & 0 & 6 & 6 & 0 & 0 & 27 & 26 & 1 & 0 & 6 & 5 & 1 & 0 \\
\hline
\end{tabular}

iMLS, inducible expression of clindamycin resistance

cMLS, constitutive expression of clindamycin resistance

MS, erythromycin-resistant, clindamycin-susceptible, no induction

CoN S. aureus ${ }^{a}$, coagulase-negative S. aureus

CoP S. aureus ${ }^{b}$, coagulase-positive S. aureus 
which then renders the respective staphylococcal isolate resistant to all 14-, 15-, and 16-membered macrolides, lincosamides and streptogramin B antibiotics [23-25]. Therefore, different conformational rearrangements in the mRNA structure or structural alterations (deletions, duplications or mutations) in the upstream regulatory region of erm genes could be one of the plausible reasons of our isolates and such resistance mechanism will be further studied.

Other resistance genes may also play a role in the sensitivity to 16-membered macrolides. For example, $m s r(A) / m s r(B)$ genes in CoPSA isolates. These genes encode an inducible efflux pump which is an $A B C$ transporter. 14- and 15-membered macrolides are inducers and substrates for the pump, while clindamycin is neither an inducer nor a substrate [8]. In our research, all $6 \mathrm{msr}(A) / m s r(B)$-carrying CoPSA isolates were also $\operatorname{erm}(B)$ and/or $\operatorname{erm}(C)$ genes positive. These isolates had the iMLS phenotype and exhibited MICs of $\geq 256 \mu \mathrm{g} / \mathrm{mL}$ for erythromycin while susceptible to 16-membered macrolides spiramycin and/or tylosin. However, the situation is much complicated for $51 \mathrm{msr}(A) / m s r(B)$-carrying CoNS isolates. Among them, 31 (17 S. haemolyticus, 7 S. aureus, 4S. epidermidis and $3 S$. chromogenes) had the iMLS phenotype, 15 (9 S. haemolyticus, 2 S. simulans, 2 S. hyicus, 1 S. epidermidis and $1 S$. chromogenes) had the cMLS phenotype and 5 (2 S. warneri, 1 S. sciuri, 1 S. aureus and 1 S. saprophyticus) had the MS phenotype.

\section{Characterization of MLS resistance genotypes in erythromycin-susceptible isolates}

Among 81 erythromycin-susceptible (ER-S) CoPSA isolates, 79 isolates were positive for $\operatorname{lnu}(A), 69$ for $\operatorname{erm}(C)$, 47 for $m p h(C), 66$ for $\operatorname{erm}(B), 64$ for $m s r(A) /(B), 20$ for $\operatorname{ere}(A)$ and 10 for $\operatorname{vga}(A)$ genes (Table 5), but all were susceptible to the corresponding antibiotics (erythromycin, azithromycin, spiramycin, tylosin or clindamycin) in the antibiotic susceptibility testing, due to unknown reasons. As for 32 ER-S CoNS isolates, 7, 9, 20, 11, 7 and 9 CoNS isolates harbored $\operatorname{erm}(B), \operatorname{erm}(C)$, $m s r(A) /(B), \operatorname{mph}(C)$, ere $(A), v g a(A)$ genes, respectively (Table 5). Furthermore, the lincosamide nucleotidyltransferase gene, $\ln u(A)$, was detected in all ER-R $S$. aureus, ER-R CoNS isolates, ER-S CoNS and 79 ER-S CoPSA isolates (Table 3; Table 5). The presence of $\ln u(A)$ among staphylococcal isolates from bovine mastitis has been reported $[5,10,12]$. The $\ln u(A)$ gene is mainly carried by small rolling-circle plasmids and it mediates only a low-level of resistance to the lincosamide pirlimycin [10]. The $\operatorname{ere}(A)$ gene was detected for the first time in staphylococci of bovine milk origin. Our results are in agreement with previous studies which detected $\operatorname{erm}(C), \operatorname{lnu}(A), \operatorname{mph}(C)$ or $\operatorname{erm}(A)$ genes in susceptible $S$. aureus or CoNS isolates [12, 26, 27]. When Martineau et al. [26] subcultured 4 erythromycin susceptible strains harboring the $\operatorname{erm}(C)$ gene with increasing concentration of the antibiotic, they found that those susceptible strains all become resistant. Thus, we need to be vigilant when we use MLS antibiotics on dairy farms.

\section{Conclusions}

In summary, a very high rate of iMLS (95\%, 38/40) phenotype of ER-R S. aureus and MLS resistance phenotype $(67 \%, 65 / 97)$ of CoNS isolates from milk of mastitic cows was found in this study in comparison with previous studies, presumably due to extensive use of MLS antibiotics in dairy cows in our region. Our results suggest that MLS antibiotics should be used judiciously for therapeutic and prophylactic intervention of staphylococci infection.

Table 5 MLS resistance genes in 81 ER-S coagulase-positive S. aureus and 32 ER-S CoNS isolates

\begin{tabular}{|c|c|c|c|c|c|c|c|c|c|c|c|c|c|c|c|c|}
\hline \multirow[t]{2}{*}{ Species } & \multirow{2}{*}{$\begin{array}{l}\text { Total } \\
\text { number }\end{array}$} & \multirow{2}{*}{$\begin{array}{l}\text { Erythromycin- } \\
\text { susceptible } \\
\text { number }\end{array}$} & \multicolumn{2}{|c|}{ ermB } & \multicolumn{2}{|c|}{ ermc } & \multicolumn{2}{|c|}{$m s r A / B$} & \multicolumn{2}{|c|}{ mphC } & \multicolumn{2}{|c|}{ ereA } & \multicolumn{2}{|c|}{$\ln u A$} & \multicolumn{2}{|c|}{$\operatorname{vgaA}$} \\
\hline & & & $n$ & $\%$ & $\mathrm{n}$ & $\%$ & $\mathrm{n}$ & $\%$ & $n$ & $\%$ & $\mathrm{n}$ & $\%$ & $\mathrm{n}$ & $\%$ & $\mathrm{n}$ & $\%$ \\
\hline S. chromogenes & 11 & 5 & 1 & 20 & 1 & 20 & & & 2 & 40 & 3 & 60 & 5 & 100 & & \\
\hline S. sciuri & 9 & 7 & 1 & 14.3 & 1 & 14.3 & 4 & 57.1 & 7 & 100 & 1 & 14.3 & 7 & 100 & & \\
\hline S. warneri & 2 & 0 & & & & & & & & & & & & & & \\
\hline S. haemolyticus & 31 & 1 & 1 & 100 & & & & & & & & & 1 & 100 & & \\
\hline S. epidermidis & 7 & 1 & & & 1 & 100 & 1 & 100 & & & 1 & 100 & 1 & 100 & & \\
\hline S. hyicus & 3 & 0 & & & & & & & & & & & & & & \\
\hline S. saprophyticus & 1 & 0 & & & & & & & & & & & & & & \\
\hline S. simulans & 5 & 1 & & & & & 1 & 100 & & & 1 & 100 & 1 & 100 & 1 & 100 \\
\hline CoN S. aureus ${ }^{a}$ & 28 & 17 & 4 & 23.5 & 6 & 35.3 & 15 & 88.2 & 2 & 11.8 & 1 & 5.9 & 17 & 100 & 8 & 47.1 \\
\hline Total CoNS & 97 & 32 & 7 & 21.9 & 9 & 28.1 & 20 & 62.5 & 11 & 34.4 & 7 & 21.9 & 32 & 100 & 9 & 28.1 \\
\hline CoP S. aureus ${ }^{b}$ & 121 & 81 & 66 & 81.5 & 69 & 85.2 & 64 & 79 & 47 & 58 & 20 & 24.7 & 79 & 97.5 & 10 & 12.3 \\
\hline
\end{tabular}




\section{Abbreviations}

CMLS: constitutive MLS resistance phenotype; CoNS: Coagulase-negative staphylococci; CoPSA: coagulase-positive Staphylococcus aureus;

ER-R: erythromycin-resistant; ER-S: erythromycin-susceptible.; iMLS: inducible MLS resistance phenotype; MIC: Minimal inhibitory concentration MLS: macrolide-lincosamide-streptogramin.

\section{Competing interests}

The authors declare that they have no competing interests.

\section{Authors' contributions}

LPL and XZ conceived and designed the experiments; LPL, WWF, ZPZ and HPX conducted the laboratory experiments; LPL and XZ performed the data analysis; LPL and XZ wrote the manuscript. All authors read and approved the final manuscript.

\section{Acknowledgments}

This study was financially supported by a grant from the National Science Foundation of China (31372282), the China Thousand Talents Program and a University Scientific Research Fund project (Fund No. Z111021305). This work was also partially supported from a discovery grant by Natural Science and Engineering Research Council of Canada.

Received: 18 January 2015 Accepted: 16 July 2015

Published online: 25 July 2015

\section{References}

1. Pyorala S, Taponen S. Coagulase-negative staphylococci-emerging mastitis pathogens. Vet Microbiol. 2009;134(1-2):3-8.

2. Taponen S, Pyorala S. Coagulase-negative staphylococci as cause of bovine mastitis-Not so different from Staphylococcus aureus? Vet Microbiol. 2009:134(1-2):29-36.

3. Frey Y, Rodriguez JP, Thomann A, Schwendener S, Perreten V. Genetic characterization of antimicrobial resistance in coagulase-negative staphylococci from bovine mastitis milk. J Dairy Sci. 2013;96(4):2247-57.

4. Sawant AA, Gillespie BE, Oliver SP. Antimicrobial susceptibility of coagulase-negative staphylococcus species isolated from bovine milk. Vet Microbiol. 2009;134(1-2):73-81.

5. Wang Y, Wu CM, Lu LM, Ren GWN, Cao XY, Shen JZ. Macrolide-lincosamideresistant phenotypes and genotypes of Staphylococcus aureus isolated from bovine clinical mastitis. Vet Microbiol. 2008;130(1-2):118-25.

6. McDougall S, Agnew KE, Cursons R, Hou XX, Compton CRW. Parenteral treatment of clinical mastitis with tylosin base or penethamate hydriodide in dairy cattle. J Dairy Sci. 2007;90(2):779-89.

7. Poehlsgaard J, Douthwaite $\mathrm{S}$. The bacterial ribosome as a target for antibiotics. Nat Rev Microbiol. 2005;3(11):870-81.

8. Depardieu F, Podglajen I, Leclercq R, Collatz E, Courvalin P. Modes and modulations of antibiotic resistance gene expression. Clin Microbiol Rev. 2007;20(1):79-114

9. Leclercq R. Mechanisms of resistance to macrolides and lincosamides: Nature of the resistance elements and their clinical implications. Clin Infect Dis. 2002;34(4):482-92.

10. Lüthje P, von Köckritz-Blickwede M, Schwarz S. Identification and characterization of nine novel types of small staphylococcal plasmids carrying the lincosamide nucleotidyltransferase gene Inu(A). J Antimicrob Chemother. 2007:59(4):600-6.

11. Roberts MC. Resistance to tetracycline, macrolide-lincosamidestreptogramin, trimethoprim, and sulfonamide drug classes. Mol Biotechnol. 2002;20(3):261-83

12. Lüthje P, Schwarz S. Antimicrobial resistance of coagulase-negative staphylococci from bovine subclinical mastitis with particular reference to macrolide-lincosamide resistance phenotypes and genotypes. J Antimicrob Chemother. 2006:57(5):966-9.

13. Ochoa-Zarzosa A, Loeza-Lara PD, Torres-Rodriguez F, Loeza-Angeles $\mathrm{H}_{\text {, }}$ Mascot-Chiquito N, Sanchez-Baca S, et al. Antimicrobial susceptibility and invasive ability of Staphylococcus aureus isolates from mastitis from dairy backyard systems. Anton Leeuw Int J G. 2008:94(2):199-206.

14. Li LP, Zhou LX, Wang LH, Xue HP, Zhao X. Characterization of methicillin-resistant and -susceptible staphylococcal isolates from bovine milk in Northwestern China. PLoS One. 2015;10(3):e0116699.
15. Clinical and Laboratory Standards Institute. Performance Standards for Antimicrobial Disk and Dilution Susceptibility Tests for Bacteria Isolated from Animals: Informational supplement. CLSI document 2004, M31-S1. Wayne, PA

16. Swedish Antibiotic Utilisation and Resistance in Human Medicine (SWEDRES) and Swedish Veterinary Antimicrobial Resistance Monitoring (SVARM). Use of antimicrobials and occurrence of antimicrobial resistance in Sweden. Solna/Uppsala: SWEDRES-SVARM Document; 2012.

17. Clinical and Laboratory Standards Institute. Performance Standards for Antimicrobial Susceptibility Testing; Twenty-First Informational Supplement CLSI document. 2011;31(1):M100-S21

18. Lina G, Quaglia A, Reverdy ME, Leclerca R, Vandenesch F, Etienne J. Distribution of genes encoding resistance to macrolides, lincosamides, and streptogramins among staphylococci. Antimicrob Agents Chemother. 1999;43(5):1062-6.

19. Sutcliffe J, Grebe T, TaitKamradt A, Wondrack L. Detection of erythromycinresistant determinants by PCR. Antimicrob Agents Chemother 1996:40(11):2562-6.

20. Werner G, Cuny C, Schmitz FJ, Witte W. Methicillin-resistant, quinupristin-dalfopristin-resistant Staphylococcus aureus with reduced sensitivity to glycopeptides. J Clin Microbiol. 2001;39(10):3586-90.

21. Entorf M, Feßler AT, Kadlec K, Kaspar H, Mankertz J, Peters T, et al. Tylosin susceptibility of staphylococci from bovine mastitis. Vet Microbiol. 2014;171(3-4):368-73.

22. Pfister $\mathrm{P}$, Jenni S, Poehlsgaard J, Thomas A, Douthwaite S, Ban N, et al. The structural basis of macrolide-ribosome binding assessed using mutagenesis of 23 S rRNA positions 2058 and 2059. J Mol Biol. 2004:342(5):1569-81.

23. Lüthje P, Schwarz S. Molecular analysis of constitutively expressed erm(C) genes selected in vitro in the presence of the non-inducers pirlimycin, spiramycin and tylosin. J Antimicrob Chemother. 2007;59(1):97-101.

24. Daurel C, Huet C, Dhalluin A, Bes M, Etienne J, Leclerca R. Differences in potential for selection of clindamycin-resistant mutants between inducible erm(A) and erm(C) Staphylococcus aureus genes. J Clin Microbiol. 2008:46(2):546-50.

25. de Vries LE, Christensen H, Agerso Y. The diversity of inducible and constitutively expressed erm(C) genes and association to different replicon types in staphylococci plasmids. Mobile Genetic Elements. 2012;2(2):72-80.

26. Martineau F, Picard FJ, Lansac N, Menard C, Roy PH, Ouellette M, et al. Correlation between the resistance genotype determined by multiplex PCR assays and the antibiotic susceptibility patterns of Staphylococcus aureus and Staphylococcus epidermidis. Antimicrob Agents Chemother. 2000:44(2):231-8

27. Spiliopoulou I, Petinaki E, Papandreou P, Dimitracopoulos G. erm(C) is the predominant genetic determinant for the expression of resistance to macrolides among methicillin-resistant Staphylococcus aureus clinical isolates in Greece. J Antimicrob Chemother. 2004;53(5):814-7.

\section{Submit your next manuscript to BioMed Central and take full advantage of:}

- Convenient online submission

- Thorough peer review

- No space constraints or color figure charges

- Immediate publication on acceptance

- Inclusion in PubMed, CAS, Scopus and Google Scholar

- Research which is freely available for redistribution 